\title{
INFORMATION SYSTEM FOR HIGHER EDUCATION IN SLOVENIA
}

\author{
Duša Marjetič, Ministry of Education, Science and Sport, dusa.marjetic@gov.si \\ Dušan Lesjak, University of Primorska, Faculty of Management, dusan.lesjak@fm-kp.si
}

\begin{abstract}
The Ministry of Education, Science and Sports established a so-called eVŠ system - Records and analytical information system for higher education (HE) in the Republic of Slovenia. eVS performs two roles - it is a tool for various HE stakeholders to rationalize their time and costs, and an analytical tool that facilitates evidencebased HE policy-making for further development of the HE system. This paper presents eV $\breve{S}$ records and particularly its analytical capabilities, together with its key impacts and further potential of its analytical capabilities.
\end{abstract}

Keywords: Information System (IS), High Education (HE), Republic of Slovenia, eVŠ

\section{INTRODUCTION}

The Ministry of Education, Science and Sport established a records and analytical information system for higher education in the Republic of Slovenia (eVŠ) at the end of 2012 (MESS, 2012), which includes data on higher education institutions (HEIs), publicly verified study programmes, students and graduates. The eVŠ is an analytical tool that facilitates regular monitoring of educational system's operations, and the development and streamlining of HE policies. As a central source of data on student status, the eVŠ also helps to verify students' eligibility for public subsidies and different forms of financial aid instruments (Education Policy..., 2015).

Since its establishment and in the first three years of use, the following two goals have been achieved:

- That the eVŠ is populated with all current data on key stakeholders/HE system elements - students, HEIs, study programmes and opportunities for student grants, and

- That as many users as possible decide to use the eVŠ information system, thereby simplifying and speeding up their work, as well as increasing its clarity and effectiveness.

It is therefore time to enter the second phase of the eVŠ rollout and maximise its potential as an analytical tool to inform evidence-based HE policy-making. This will contribute to a more efficient HE system as a whole and to a more prudent and rational use of public funds for $\mathrm{HE}$ in particular.

The purpose of this article is to explore the idea behind the eVS̆, how the information system was put in place, what are its impacts on the higher education system, and what are its potentials for further development. With this in mind, this paper firstly presents what the eVŠ system is, the reasons for its development, the level of spend on its development and maintenance, which database sets it encompasses, who its users are, and its functionality, particularly for the students - a choice of study programmes and various forms of financial aid.

Furthermore, we present the impacts of its use, particularly the impact on the number of students, the reduction of costs and time required to submit proof of student status to various institutions, and the simplification of the enrolment process and administrative procedures; and therefore how eVŠ is making the digital agenda a reality.

The paper concludes with an outline of future plans in eVŠ development, particularly with regards to capturing data from other existing databases for the purpose of analysis and the strengthening of the analytical role of the eVŠ, for the purpose of evidence-based policy-making in HE and systematic monitoring of employability of HE graduates, as well as to improve the responsiveness of the education system to labour market needs and of course to contribute further to the government's efforts to implement the digital agenda. 
eV̌s

\section{What is the eV̌̌?}

The eVŠ was developed for the purpose of:

- determining students' eligibility to study and access other rights chargeable to public funds,

- HE policy-planning and the monitoring of the HE system,

- the monitoring of a network of HEIs and study programmes,

- provision of public information, and

- for research, analytical and statistical purposes, i.e. for the implementation of statistical, social and economic and other research activities in the area of HE.

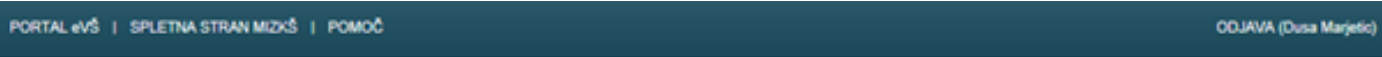

\section{eVక}

Records and analytical information system for

higher education in the Republic of Slovenia

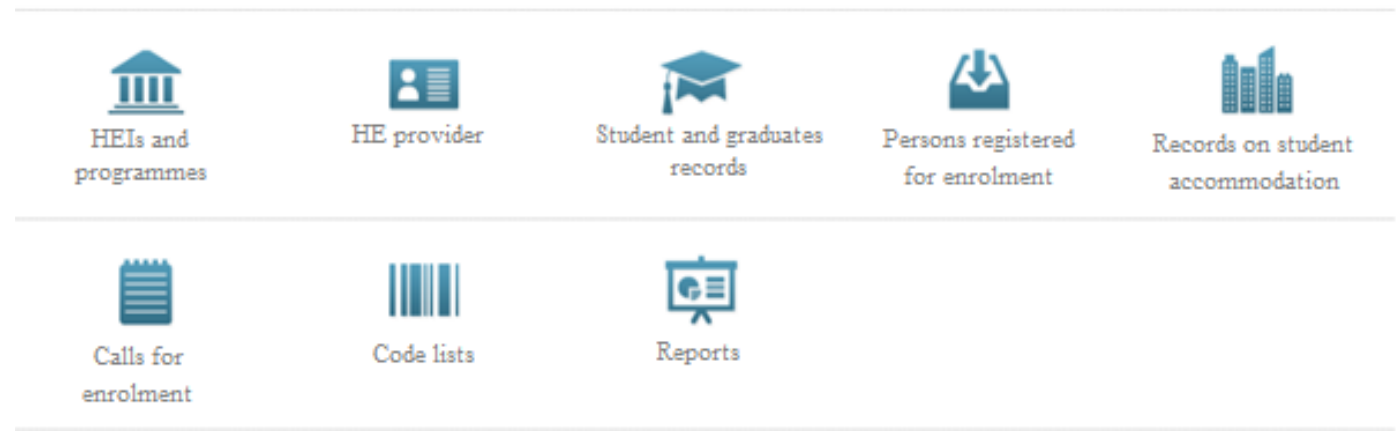

Figure 1. Home Page of the eVŠ Information System on User Login

The eVŠ includes a database with the following records:

- HEIs records,

- $\quad$ student and graduate records,

- records of study programmes,

- records of calls for enrolment,

- records of persons registered for enrolment,

- records of persons who have applied for subsidised student accommodation,

- HE provider records (HE professors).

It also enables online submission of applications and provides support with the selection procedure for:

- applications for HE study programmes,

- $\quad$ subsidised student accommodation applications.

In the period from 2011 to 2015 , over a million records were created in the eVŠ, including records on student enrolment $(995,178)$, student mobility $(22,585)$, HEIs $(311$ records on 116 HEIs: 5 universities and 45 independent HEIs), study programmes (4,105 records on 1,997 study programmes), enrolment applications $(98,218)$, applications for subsidised university and private dormitories and other private accommodation $(75,138)$.

To develop the eVŠ, so-called common application building blocks for electronic data exchange were used, which were developed by the Ministry of Public Administration. This lowered the costs of development and improved the coherence of information solutions in the public sector. Common application building blocks are a 
technical solution that enables public institutions to have a simpler, more cost-effective and faster development of an information system, so they can better focus on data content and process optimisation. Building blocks include a system for standardized management of users and their rights (Security Platform), system for standardized execution of data enquiry (Tray), standardized platform for data distribution (IO-module), and system for electronic enquires to the data sources where synchronous access is not possible (MPA, 2015).

The total expenditure on the eVŠ system between 2011 and 2014 was 979,528.82 EUR (2011: 425,422.63 EUR, 2012: 297,819.60 EUR, 2013: 150,472.24 EUR, 2014: 105,814.35 EUR). A further expenditure of 75,600 EUR is planned in 2015 (Review..., 2015).

In the budget adopted for 2016 and 2017, the following has been allocated for the eVŠ: 240,000 EUR for 2016, 240,000 EUR for 2017, and 81,883 EUR for 2018 (Adopted Budget..., 2016). Additional funds of 264,000 EUR are being provided for the development of a new analytical tool in 2016-2017 as part of the Operational Programme for the Implementation of the EU Cohesion Policy 2014-2020 (Overview..., 2015).

\section{Usage and Users of the eVŠ data}

Student and graduate records in the eVS are the official source of information on student status, used by public institutions that grant scholarships and subsidies for meals, transport, and dormitories, as well as the offices for health insurance, pensions, student work, employment agency, and national statistics.

In 2015 , the eVŠ recorded 1,491,463 views of student data. The following user groups use the data held in the eVŠ (MESS, 2016A):

- Candidates who use the eVŠ to fill in electronic application forms for enrolment into study programmes or for subsidised accommodation. In 2015, eVŠ users filled in 67,101 electronic applications $(48,720$ applications for enrolment and 18,381 applications for accommodation).

- Offices for student dormitories that use the eVŠ module for subsidised accommodation, which supports the administrative processing of applications for subsidised student accommodation.

- Employees of HEIs and ministries who access the records of students and graduates who applied for enrolment, and the records of HE study programmes (in 2015, the eVŠ had 392 registered users).

- Institutions that grant benefits and rights to public funds tied to student status access the data held in student and graduate records. They process the data with the purpose of checking the students' status to establish eligibility for:

- Ministry of Education, Science and Sport: subsidised dormitories, and publicly financed full-time studies in tertiary education.

- Slovenian Student Union: subsidised meals.

- Ministry of Infrastructure: subsidised transport.

- Centres for Social Work: government scholarships and financial welfare assistance.

- Slovene Human Resources Development and Scholarship Fund: scholarships.

- Health Insurance Institute of Slovenia: health insurance.

- Pension and Disability Insurance Institute: entitlement to pension due to a deceased parent.

- Employment Service of Slovenia: support for the unemployed.

- Student Services: student work.

- Statistical Office of the Republic of Slovenia uses data on HEIs, study programmes, students, and graduates for national statistics.

Data on HEIs and study programmes includes a national code list used by databases of HEIs, national statistical office, and other public institutions (Ministry of Labour, Family, Social Affairs and Equal Opportunities, Employment Service of Slovenia on the http://ec.europa.eu/ploteus/en website, The Centre of the Republic of Slovenia for Mobility and European Educational and Training Programmes on the www.studyinslovenia.si website, University of Ljubljana).

The electronic enrolment application is the central point of enrolment into Slovenian HEIs. The application form is available in Slovene and English. For applicants, a single point of support is provided by the ministry first level resolves technical queries regarding the filling in of the form and general questions on rules and procedures for enrolment into HE; requests for more detailed information on study programmes are passed on to HEIs. 
In January 2016, publicly available data held in the eVŠ was published on the http://portal.evs.gov.si/ website in Slovene. An English version of the website was not developed as this role was taken on by the http://studyinslovenia.si/ website, which uses the data from the eVŠ.

As part of the effort to inform pupils, students, and other interested public about HE, a free eVŠ mobile application was released in May 2015, which collates all of the important information on HE in Slovenia in one place. The users can search the data on HEIs, study programmes, and subsidized meals that is gathered in the app. It also provides important information on student rights and benefits that take student's status into account: scholarships, subsidies for transport, meals, and accommodation, health insurance, and student work.

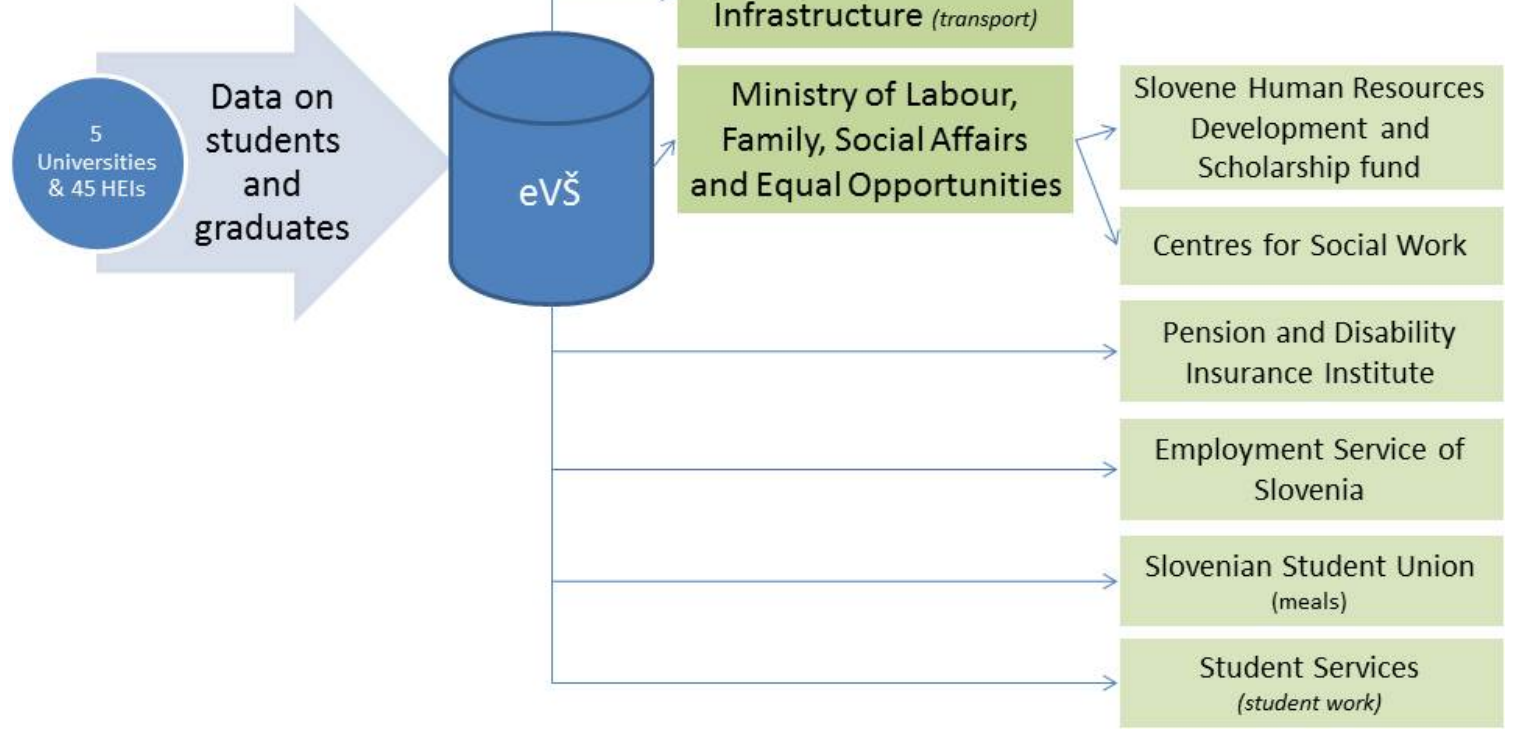

Figure 2. Institutions Using Data on Students and Graduates Held in the eVŠ

\section{IMPACTS OF eVŠ}

Control mechanisms that are built into both the application for enrolment and the transmission of data from HEIs to eV ̌̌ have already successfully prevented the enrolment of students who are no longer entitled to publicly funded full-time studies in tertiary education (both higher education and short cycle vocational higher education). This reflects in a decrease in the number of enrolled students, which exceeds the decrease expected as a result of demographic changes. The total number of students fell by 20,460 between the 2011/12 academic year, when 90,142 students were enrolled, and the 2015/16 academic year with 69,682 students (MESS, 2016). Table 1 below shows that in the past five years, following the introduction of the eVŠ, the number of students has fallen by $22.7 \%$ (including a decrease of $21.6 \%$ in the number of students enrolled in the $1^{\text {st }}$ year of undergraduate studies), while the number of 19 -year-olds decreased only by $10.1 \%$. The reduction in the number of students can therefore be attributed to the eV ̌ to some extent. 
Table 1. Number of Students and Demographic Trends

\begin{tabular}{|c|c|c|c|c|c|c|}
\hline $\begin{array}{c}\text { Academic } \\
\text { year }\end{array}$ & $\begin{array}{c}\text { \# of all } \\
\text { enrolled } \\
\text { students }\end{array}$ & $\begin{array}{c}\text { Chain } \\
\text { index }\end{array}$ & $\begin{array}{c}\text { \# of enrolled students in } \\
\text { the 1st year of } \\
\text { undergraduate studies } \\
\text { for the 1 } \mathbf{1}^{\text {st }} \text { time }\end{array}$ & $\begin{array}{c}\text { Chain } \\
\text { index }\end{array}$ & $\begin{array}{c}\text { \# of 19-year- } \\
\text { olds }\end{array}$ & $\begin{array}{c}\text { Chain } \\
\text { index }\end{array}$ \\
\hline $2011 / 12$ & 90,142 & 100 & 18,593 & 100 & 22,141 & 100 \\
\hline $2012 / 13$ & 86,142 & 96 & 17,736 & 95 & 20,634 & 93 \\
\hline $2013 / 14$ & 79,267 & 88 & 16,265 & 87 & 20,430 & 92 \\
\hline $2014 / 15$ & 74,046 & 82 & 15,098 & 81 & 20,231 & 91 \\
\hline $2015 / 16$ & 69,682 & 77 & 14,584 & 78 & 19,719 & 89 \\
\hline
\end{tabular}

Sources: SORS 2016, and MESS 2016.

The system has become the official source of information on student status for public institutions that use this data in their procedures, as outlined in the previous section. Furthermore, the setting-up of online services for data transmission has almost entirely eliminated paper-based processes of collecting and reviewing paper copies of enrolment certificates, which the students had to personally submit. Electronic operation also reduced the costs for both institutions and users, as they are no longer required to post or submit the certificate in person. The Ministry of Public Administration conducted an analysis of cost savings achieved as a result of the creation of an electronic data collection method in the field of HE, which was one of the measures agreed to reduce both the administrative barriers in public sector and the burden on citizens. It was estimated that annualy eVS̆ realizes 800.000 EUR of savings (MPA, 2016). Electronic data exchange delivers savings in postage costs, as well as in time spent on manual data entry into various information systems.

A unified application for enrolment into HE study programmes has led to the optimisation of processes and simplification of administrative procedures. For the opening of the enrolment application deadline in the eVŠ HEIs must send a call for enrolment, which includes a set of mandatory data on the enrolment requirements and selection procedures. All calls for enrolment are published publicly together on the same web page, this means that candidates do no longer have to search for information on web pages of individual HEIs. To simplify an administrative procedure for recognition of foreign education the electronic application form for enrolment has been amended for the 2016/17 academic year, to include the elements of the application form for recognition of foreign education, which was previously a separate form. In order to avoid duplication of application forms and documentation the candidates will be able to use the same form for both procedures: the admission process and the foreign education certificate recognition process. In the 2015/16 academic year, $8.9 \%$ of all applications for enrolment were submitted by foreigners, who, in addition to submitting an application for enrolment, also had to submit to the HEIs an application for recognition of previous education for the purpose of further education. To introduce this simplification, the legislation (ministerial regulations) had to be amended, and processes of administrative processing of applications for enrolment and recognition of foreign education had to be adjusted.

The eVŠ also acts as an important player in the realisation of the digital agenda. An electronic application for enrolment and for accommodation can be submitted with a digital certificate. In $2015,20 \%$ of all electronic applications were submitted with a digital certificate, while the other $80 \%$ were entered into the eVŠ and then printed and signed, and sent by post or delivered to HEIs in person. The use of digital certificate is being promoted in cooperation with the Ministry of Public Administration, which has, jointly with local authorities, enabled the delivery of a registry service for SIGEN-CA digital certificates at Slovenian secondary schools. Registry service officers spend a day or two at each school to accept applications for a digital certificate and confirm the identity of the applicants (Marjetic et al., 2014).

\section{FUTURE PLANS}

In the first few years of eVŠ operation, the emphasis was on the development and data collection. Now that most data on students and their study, applications for enrolment, and HEIs and their study programmes has


acquired from other existing databases for the purpose of analysis, such as, for instance, information on 
scholarships, subsidised transport, types of support sought by graduates from the Employment Service of Slovenia to find the first job, etc.

In the next period, up to 2020 , the ministry plans to strengthen the analytical role of the eVŠ. The aim is for the eV ̌̌ to become an analytical tool to support evidence-based policy-making in HE that is available also to HEIs, and to connect data held in the eVŠ with data from other public records. This will enable an analysis of students' path from secondary to tertiary education and on to the labour market (Education..., 2015).

As part of the eVŠ, a systematic monitoring of the employability of HE graduates will be established to improve the responsiveness of the education system to labour market needs, which is a measure planned by the national development programme. By 2020, a tool will be developed within the eVŠ to support the monitoring of the performance of students and the transition of graduates into the labour market, which will assist policy makers in formulating comprehensive policies in the field of education and with regards to rights to public funds that are contingent on student status (scholarships, meals, transportation, accommodation, health insurance, pension). It will also assist HEIs with self-evaluation and formulation of study programmes (Operational Programme..., 2014).

As part of the government's efforts to implement the digital agenda, there are ongoing activities to increase the use of digital certificates and thereby the number of applications submitted with an electronic signature. To increase the level of electronic operations, further development is needed in the following areas:

- Administrative operations of HEIs must change so that on submission of an application for enrolment, applicants will no longer be required to submit supporting documentation in paper format and will be able to submit a scanned copy through the eVŠ together with the application;

- Availability of the option to submit an electronic application form with a digital certificate in public administration must increase;

- The existing electronic signature method must be simplified and must become independent of browsers and devices used by the user.

\section{SUMMARY}

It is apparent that within the space of only a few years, the eVŠ has become an excellent tool for many HE stakeholders: the applicants, who in 2015 filled in 67,101 electronic forms (48,720 applications for enrolment and 18,381 applications for accommodation), Offices for student dormitories that use the eVŠ module for subsidised accommodation, which supports administrative processing of applications for subsidised student accommodation, employees of HEIs and ministries who access the records of students and graduates who applied for enrolment, and the records of HE study programmes (in 2015, the eVŠ had 392 registered users), and public institutions that no longer need to collect enrolment certificates - in 2015, the eVŠ recorded $1,491,463$ views of student data.

For this reason, the eVŠ should be used as an analytical tool as far as possible: to inform evidence-based HE policy-making, for the systematic monitoring of the employability of HE graduates to improve the responsiveness of the education system to labour market needs, and to contribute to the government's efforts to implement the digital agenda, which in turn will contribute to a more efficient HE system as a whole and to a more prudent and rational use of public funds for HE in particular.

\section{REFERENCES}

Adopted Budget of the RS 2016, Ministry of Finance. (2015): Available at: http://www.mf.gov.si/fileadmin/mf.gov.si/pageuploads/Prora\%C4\%8Dun/Sprejeti_prora\%C4\%8Dun/2 016/SP2016_NRP.pdf

Education and Training - Monitor 2015; European Commission, Directorate-General for Education and Culture: Available at: http://ec.europa.eu/education/tools/docs/2015/monitor2015-slovenia_en.pdf

Education Policy Outlook 2015, OECD (page 290); Available at: http://www.oecd.org/edu/education-policyoutlook-2015-9789264225442-en.htm 
Marjetic, D., Degen, T., \& Kravos, A. (2014). eV ̌̌ - Transition from Records to a Strategic Analytical Tool; Bertok, J. et al. (eds.), Proceedings of the Informatics in Public Administration Conference 2014. (electronic source) Congress centre Brdo pri Kranju, 8-9 December 2014.

MESS - Ministry of Education, Science and Sport (2016). Available at: http://www.mizs.gov.si/si/ delovna_podrocja/direktorat_za_visoko_solstvo/sektor_za_visoko_solstvo/statistika_in_analize_s_pod rocja_visokega_solstva/

MESS - Ministry of Education, Science and Sport (2016A). Available at: http://www.mizs.gov.si/si/delovna_podrocja/direktorat_za_visoko_solstvo/evs/\#c18410

MESS - Ministry of Education, Science and Sport (2012). Available at: http://www.mizs.gov.si/fileadmin/ mizs.gov.si/pageuploads/Visoko_solstvo/eVS/dopis_vzpostavitevESD_17-12.pdf

MPA - Ministry of Public Administration: Common building blocks for electronic data exchange (2015). Available at: https://www.youtube. com/watch?v=70dxReNOvT4

MPA - Ministry of Public Administration: Reduction of regulatory burdens from 2009 to 2015 (2016). Available at: http://www.stopbirokraciji.si/fileadmin/user_upload/mju/English/Publication/Brosura_MJU_FINAL _eng3small.pdf

Operational Programme for the Implementation of the EU Cohesion Policy 2014-2020 (2014). EU Structural and Investment Funds. Available at: http://www.eu-skladi.si/sl/dokumenti/kljucnidokumenti/op_ang_final_web.pdf

Overview of the Implementation Plan, Broken Down by Priority Axes for the Programming Period 2014-2020 (2015). Government Office for Development and European Cohesion Policy. Available at: http://www.svrk.gov.si/fileadmin/svrk.gov.si/pageuploads/KP_20142020/INOP_sprejetno_na_dopisni_seji_VRS_2.gradivo_150731.pdf

Review of the Realization of Strategic Goals of Higher Education in the RS, which Form the Basis for the Planning and Implementation of the OP 2014 - 2020 in the Field of Higher Education (2015), MK projekt, 26 November 2015. Available at: http://www.eu-skladi.si/sl/dokumenti/studije-invrednotenja/stratesko-vrednotenje-vs-koncno-porocilo.pdf

SORS - Statistical Office of the Republic of Slovenia (2016), SI-STAT Data Portal, Demography and social statistics: Population by age and sex. Available at: http://pxweb.stat.si/pxweb/Dialog/varval.asp?ma= 05C1002E\&ti=\&path=../Database/Demographics/05_population/10_Number_Population/05_05C10_P opulation_kohez/\&lang=1 